\title{
Research Review and Hotspots Analysis of Vocational Education in China: \\ Based on the Statistics of the Paper Output of the National Education Science Planning Project from 2015 to 2019
}

\author{
Gao $\mathrm{Yu}^{1}$ \\ ${ }^{1}$ Department of Vocational and Technical Education, Xi 'an University of Architecture and Technology, Xi 'an, Shaanxi, 710055, China
}

\begin{abstract}
Using the bibliometric method, the paper output of Vocational Education Project of the National Education Science Planning from 2015 to 2019 were analyzed statistically according to the project type, journal, author, institution and high-frequency keywords. The statistical results show that the number of papers supported by the National Project is superior to that of the Ministry of Education, which indicates that the scientific research team of the National Project has a strong strength. More than half of the papers were published in core journals. Researchers from universities and vocational colleges jointly constitute the most high-yield authors. High-yield institutions are mainly composed of universities, while the vocational colleges need to be strengthened. The research focuses on the integration of industry and education, modern apprenticeship, Double High Plan, foreign vocational education and training, etc.
\end{abstract}

\section{Introduction}

The National Education Science Planning Project is currently the highest-level and most authoritative fund project of educational disciplines in China, it represents the direction of educational scientific research in a certain sense. Vocational and technical education (vocational education) is a subject category funded by National Education Science Planning Project, and the projects has always been paid attention and valued by vocational education researchers. For example, Li Jifeng et al. analyzed the hotspots and trends of vocational education in China based on the two major national education research funds [1]. Ma Yanlei and Liu Yang through the quantitative analysis of the Vocational Education Project from 2006 to 2018, perspective the historical evolution and trend prospects in vocational education research [2]. However, there are few literatures that discuss the status of vocational education research from the perspective of output. With China's support for vocational education in recent years, the number of projects has been steadily increased, and a large number of output with high academic value have been accumulated. Therefore, it is necessary to sort out and summarize the output of vocational education projects from 2015 to 2019, grasp the status of vocational education research in China, focus on hotspots and subject areas. Since there are many forms of project outputs, including papers, reports, works, etc., the main form is papers, the outcome discussed in this article mainly refer to journal papers.

\section{Research Methods and Data Sources}

\subsection{Research Methods and Tool}

This paper uses the bibliometric method to quantitative analysis the paper output of Vocational Education Projects of National Education Science Planning Project from 2015 to 2019. Firstly, Bicomb2.0 software was used to analyze the external distribution characteristics of the paper, such as project type, journal, institution and author. Secondly, the keywords of the paper are counted, the high-frequency keywords are extracted and analyzed, the content characteristics of the paper are displayed, and the hotspots of vocational education research are revealed.

\subsection{Data Sources}

The research data comes from the CNKI database, the search method is "fund" = "project grant number", and the source category is academic journals. After excluding briefings, notices, and documents not related to vocational education, 981 documents were retrieved (The search date is October 30,2020). The project grant number comes from the 2015-2019 vocational education project data published on the website of the National Education Science Planning Leading Group Office. The types of National Education Science Planning Project include National Major Project, National Key Project, National General Project, National Youth Project, Key Project of 
Ministry of Education and Youth Project of Ministry of Education.

\section{Statistics and Discussion}

\subsection{Project Types of Project Papers}

This article counts the paper output of Vocational Education Project from 2015 to 2019 by project type, as shown in Table 1. 981 papers are derived from 213 Vocational Education Project of National Education Science Planning Project. No Major National Project have been approved. The largest number of projects is the national general project, the second is the Key Project of Ministry of Education. The average number of papers produced by the project is 4.6. Among them, the paper with the highest average output is National Key Project. The maximum number of papers produced by one project is 52, which is Research on the Connotation, Standards, Realization Paths and Monitoring Indicators of Vocational Education Modernization declared by Rong Changhai of Tianjin Academy of Educational Science in 2016. It can be seen that the scientific research team responsible for National Key Project is relatively strong. The average output of papers for the Project of Ministry of Education is lower than that for the National Projects, which indicates that the Project of Ministry of Education requires researchers to invest more time and energy.

Table1. Project Types Of Project Papers

\begin{tabular}{|c|c|c|c|}
\hline Project type & $\begin{array}{c}\text { Number } \\
\text { of projects }\end{array}$ & $\begin{array}{c}\text { Number } \\
\text { of papers }\end{array}$ & $\begin{array}{c}\text { Average } \\
\text { number of } \\
\text { papers }\end{array}$ \\
\hline National Key Project & 3 & 56 & 18.7 \\
\hline $\begin{array}{c}\text { National General } \\
\text { Project }\end{array}$ & 63 & 397 & 6.3 \\
\hline $\begin{array}{c}\text { National Youth } \\
\text { Project }\end{array}$ & 10 & 72 & 7.2 \\
\hline $\begin{array}{c}\text { Key Project of } \\
\text { Ministry of } \\
\text { Education }\end{array}$ & 98 & 374 & 3.8 \\
\hline $\begin{array}{c}\text { Youth Project of } \\
\text { Ministry of } \\
\text { Education }\end{array}$ & 39 & 82 & 2.1 \\
\hline $\begin{array}{c}\text { Total } \\
\text { nit }\end{array}$ & 213 & 981 & 4.6 \\
\hline
\end{tabular}

\subsection{Source Journals of Project Papers}

In order to further reveal the spatial characteristics and laws of vocational education issues, this paper counts the journals published project papers. Journals with more than 10 papers are shown in Table 2 . It can be seen from Table 2 that more than half of the 981 papers were published in eight professional journals of vocational education, such as Chinese Vocational and Technical Education, Vocational and Technical Education, Journal of Vocational Education, Vocational and Education and other journals. In addition, the core journals with more than 10 papers are
Chinese Vocational and Technical Education, Vocational and Technical Education, Journal of Vocational Education, Education and Vocation, Adult Education and so on, combined with the statistics of the source journals of all project papers, more than half of the papers were published in core journals.

Table2. Source Journals Of Project Papers (Published $\geq 10$ Papers)

\begin{tabular}{|c|c|c|c|}
\hline SN & Journal & $\begin{array}{l}\text { Number } \\
\text { of papers }\end{array}$ & $\begin{array}{l}\text { Cumulative } \\
\text { percentage }\end{array}$ \\
\hline 1 & $\begin{array}{l}\text { Chinese Vocational and } \\
\text { Technical Education }\end{array}$ & 117 & $11.93 \%$ \\
\hline 2 & $\begin{array}{l}\text { Vocational and Technical } \\
\text { Education }\end{array}$ & 93 & $21.41 \%$ \\
\hline 3 & $\begin{array}{c}\text { Journal of Vocational } \\
\text { Education }\end{array}$ & 91 & $30.68 \%$ \\
\hline 4 & Education and Vocation & 71 & $37.92 \%$ \\
\hline 5 & $\begin{array}{l}\text { Vocational Education } \\
\text { Research }\end{array}$ & 43 & $42.30 \%$ \\
\hline 6 & $\begin{array}{l}\text { Communication of } \\
\text { Vocational Education }\end{array}$ & 34 & $45.77 \%$ \\
\hline 7 & $\begin{array}{c}\text { Contemporary Vocational } \\
\text { Education }\end{array}$ & 22 & $48.01 \%$ \\
\hline 8 & Adult Education & 21 & $50.15 \%$ \\
\hline 9 & $\begin{array}{l}\text { Research in Educational } \\
\text { Development }\end{array}$ & 19 & $52.08 \%$ \\
\hline 10 & $\begin{array}{l}\text { Modern Education } \\
\text { Management }\end{array}$ & 14 & $53.52 \%$ \\
\hline 11 & $\begin{array}{l}\text { Research in Higher } \\
\text { Engineering Education }\end{array}$ & 13 & $54.84 \%$ \\
\hline 12 & Jiangsu Education & 12 & $56.07 \%$ \\
\hline 13 & $\begin{array}{l}\text { Journal of National Academy } \\
\text { of Education Administration }\end{array}$ & 11 & $57.19 \%$ \\
\hline 14 & $\begin{array}{c}\text { Journal of Tianjin Vocational } \\
\text { Institutes }\end{array}$ & 10 & $58.21 \%$ \\
\hline 15 & $\begin{array}{c}\text { Journal of Tianjin College of } \\
\text { Commerce }\end{array}$ & 10 & $59.23 \%$ \\
\hline
\end{tabular}

\subsection{High-yield Authors of Project Papers}

The statistical analysis of the authors of the project papers can understand the highly productive and influential authors of vocational education research. The high-yield authors in this article refer to those who have published more 10 or more papers as the first author. This paper counts these high-yield authors and their citation frequency. The results are shown in Table 3 . There are 8 high-yield authors and a total of 102 papers have been published. These authors who constitute highly productive authors of project papers include researchers from both universities and vocational colleges. Among them, the author who has published the most papers is Sun Cuixiang of Tianjin University of Technology and Education with 19 papers. The top 2 to 5 authors are Cao Ye, Liu Xiao, 
Yang Libo, and Guo Guangjun. The frequency of citations can reflect the author's academic influence and the quality of papers. The top 5 authors by frequency of citations are Cao Ye, Sun Cuixiang, Guo Guangjun, Liu Jun, and Liu Xiao. They are leading scholars in vocational education research.

Table3. High-Yield Authors Of Project Papers

\begin{tabular}{|c|c|c|c|}
\hline SN & First author & Number of papers & Cited frequency \\
\hline 1 & Sun Cuixiang & 19 & 114 \\
\hline 2 & Cao Ye & 15 & 135 \\
\hline 3 & Liu Xiao & 14 & 50 \\
\hline 4 & Yang Libo & 13 & 41 \\
\hline 5 & Guo Guangjun & 11 & 93 \\
\hline 6 & Guo Da & 10 & 33 \\
\hline 7 & Lin Kesong & 10 & 32 \\
\hline 8 & Liu Jun & 10 & 71 \\
\hline
\end{tabular}

\subsection{High-yield Institutions of Project Papers}

Analyzing the author affiliation of the subject papers can evaluate to a certain extent the unit with strong scientific research strength in the field and its discipline construction [3]. The author counts the ranking of author affiliations with more than 20 papers of vocational education projects from 2015 to 2019. See Table 4 for details. The 11 institutes listed in Table 4 published a total of 398 papers, accounting for $40.57 \%$ of all paper output. They are highyield institutes for vocational education project papers. Among them, Tianjin University of Technology and Education ranked first with 96 papers, followed by Tianjin Vocational University, Jiangsu University of Technology, Tongji University, and Southwest University. It can be seen from this that the universities are still the main institutions to publish project papers, and have strong scientific research strength, while the scientific research level of vocational colleges needs to be improved.

Table4. High-Yield Institutions Of Project Papers

\begin{tabular}{|c|c|c|}
\hline SN & Institution & $\begin{array}{c}\text { Number of } \\
\text { papers }\end{array}$ \\
\hline 1 & $\begin{array}{c}\text { Tianjin University of Technology } \\
\text { and Education }\end{array}$ & 96 \\
\hline 2 & Tianjin Vocational University & 49 \\
\hline 3 & Jiangsu University of Technology & 42 \\
\hline
\end{tabular}

\begin{tabular}{|c|c|c|}
\hline 4 & Tongji University & 39 \\
\hline 5 & Southwest University & 36 \\
\hline 6 & $\begin{array}{c}\text { Zhejiang University of } \\
\text { Technology }\end{array}$ & 25 \\
\hline 7 & Shenyang Normal University & 24 \\
\hline 8 & East China Normal University & 23 \\
\hline 9 & Tianjin University & 22 \\
\hline 10 & $\begin{array}{c}\text { Beijing Normal University } \\
\text { Hebei Normal University of } \\
\text { Science and Technology }\end{array}$ & 21 \\
\hline
\end{tabular}

\subsection{High-frequency Keywords of Project Papers}

Keywords are a refined expression of the subject content or central concept of a document, and can represent the main research content of the article. Therefore, statistics and analysis of keywords in a specific field can understand the research themes and hotspots of the subject field [4]. The higher the frequency of the keywords, the more research results related to them, and the more concentrated the research content. The keywords in 981 subject papers were extracted through Bicomb2.0 software, and these keywords were manually preprocessed, including merging keywords with the same meaning. These keywords are then sorted according to their frequency of occurrence, and a total of 31 high-frequency keywords with a frequency greater than or equal to 10 are selected, as shown in Table 5. It can be seen from Table 5 that "vocational education", "higher vocational colleges", "higher vocational education", "integration of production and education", "vocational colleges", "modern apprenticeship", "schoolenterprise cooperation", " "craftsman spirit", "talent training" and "new era" are the top ten high-frequency keywords.

Table5. High-Frequency Keywords (Frequency $\geq 10$ Times)

\begin{tabular}{|c|c|c|c|c|c|}
\hline SN & Keywords & $\begin{array}{l}\text { Freq } \\
\text { uency }\end{array}$ & SN & Keywords & $\begin{array}{l}\text { Frequ } \\
\text { ency }\end{array}$ \\
\hline 1 & $\begin{array}{l}\text { vocational } \\
\text { education }\end{array}$ & 222 & 17 & $\begin{array}{c}\text { mixed } \\
\text { ownership }\end{array}$ & 15 \\
\hline 2 & $\begin{array}{c}\text { higher } \\
\text { vocational } \\
\text { colleges }\end{array}$ & 97 & 18 & $\begin{array}{c}\text { precision } \\
\text { poverty } \\
\text { alleviation }\end{array}$ & 15 \\
\hline 3 & $\begin{array}{c}\text { higher } \\
\text { vocational } \\
\text { education }\end{array}$ & 61 & 19 & $\begin{array}{c}\text { new } \\
\text { professional } \\
\text { farmer }\end{array}$ & 14 \\
\hline 4 & $\begin{array}{l}\text { integration } \\
\text { of } \\
\text { production }\end{array}$ & 60 & 20 & Belt and Road & 14 \\
\hline 5 & $\begin{array}{l}\text { vocational } \\
\text { colleges }\end{array}$ & 43 & 21 & $\begin{array}{c}\text { secondary } \\
\text { vocational } \\
\text { school }\end{array}$ & 14 \\
\hline 6 & $\begin{array}{l}\text { modern } \\
\text { apprentices } \\
\text { hip }\end{array}$ & 42 & 22 & $\begin{array}{l}\text { secondary } \\
\text { vocational } \\
\text { education }\end{array}$ & 13 \\
\hline
\end{tabular}




\begin{tabular}{|c|c|c|c|c|c|}
\hline 7 & $\begin{array}{c}\text { school- } \\
\text { enterprise } \\
\text { cooperation } \\
\end{array}$ & 35 & 23 & course & 13 \\
\hline 8 & $\begin{array}{l}\text { craftsman } \\
\text { spirit }\end{array}$ & 31 & 24 & $\begin{array}{c}1+X \text { certificate } \\
\text { system }\end{array}$ & 11 \\
\hline 9 & $\begin{array}{l}\text { talent } \\
\text { training }\end{array}$ & 23 & 25 & American & 11 \\
\hline 10 & new era & 20 & 26 & $\begin{array}{c}\text { Double } \\
\text { Qualified } \\
\text { Teacher }\end{array}$ & 11 \\
\hline 11 & $\begin{array}{l}\text { Double } \\
\text { High Plan }\end{array}$ & 19 & 27 & $\begin{array}{c}\text { vocational } \\
\text { education and } \\
\text { training }\end{array}$ & 11 \\
\hline 12 & $\begin{array}{l}\text { modernizati } \\
\text { on }\end{array}$ & 19 & 28 & governance & 11 \\
\hline 13 & Germany & 18 & 29 & path & 11 \\
\hline 14 & $\begin{array}{l}\text { rural } \\
\text { revitalizati } \\
\text { on }\end{array}$ & 17 & 30 & dilemma & 10 \\
\hline 15 & internet + & 17 & 31 & $\begin{array}{l}\text { internationaliza } \\
\text { tion }\end{array}$ & 10 \\
\hline 16 & $\begin{array}{l}\text { modernizati } \\
\text { on of } \\
\text { vocational }\end{array}$ & 16 & & & \\
\hline
\end{tabular}

\subsection{Research Hotspots}

Through the statistical analysis of high-frequency keywords of the 2015-2019 vocational education project papers, the research hotspots of vocational education generally include the following aspects: the integration of production and education, modern apprenticeship, Double High Plan, and foreign vocational education and training. Research hotspots closely follow national policies, and the research content continues to expand and deepen, both theoretical research and practical research are emphasized. At the same time, research trends in the modernization of vocational education, rural vocational education under rural revitalization, and the internationalization of vocational education under the Belt and Road initiative have gradually become prominent.

\section{Conclusion}

The State Council issued the Decision on Accelerating the Development of Modern Vocational Education in 2014 and the National Implementation Plan for Vocational Education Reform in 2019. With the support and promotion of policies, vocational education has ushered in an important stage of transition from pursuing scale expansion to improving quality. Vocational education research should play an important role in supporting, driving and leading educational reform and development [5]. As an important scientific research project of vocational education, the National Education Science Planning Project focuses on major theoretical and practical problems of vocational education under the background of important national strategies, trying to solve the key and difficult problems in the development and reform of vocational education in the new era, and contributes to the development and development of vocational education. The formulation of future policies provides theoretical support and guidance.

Through the statistical analysis the paper output of vocational education project, the following conclusions are drawn on the current status and hotspots of vocational education research in the past five years: the number of papers supported by the National Project is superior to that of the Ministry of Education project, which indicates that the scientific research team of the National project has a strong scientific research strength. More than half of the papers are published in core journals. Researchers from universities and vocational colleges together constitute high-yield authors who publish papers. In high-yield institutions, universities are the main force for publishing papers, and the level of scientific research from vocational colleges needs to be improved. From the perspective of research hotspots, it focuses on the integration of production and education, modern apprenticeship, Double High Plan, foreign vocational education and training.

Although the paper is an important output of vocational education research, it is impossible to fully reflect the overall situation of vocational education and research due to the limitation of project establishment time, subject, quantity and publication time lag. However, it can still provide a glimpse of the current situation and research hotspots of vocational education and research in China. It is hoped that the analysis of this paper will provide inspiration and reference for the future academic research and project establishment.

\section{References}

1. Li, J., Long, F., Liu, X. (2019) Research on China vocational education based on scientific research projects: hotspots and trends: a general analysis of the two national education and scientific research funds from 2015 to 2019. China Vocational and Technical Education, 27:76-81.

2. Ma, Y. L., Liu Y. (2019) Historical evolution and trend prospect of vocational education research: quantitative analysis of projects of National Educational Science Planning Project from 2006 to 2018. Vocational and Technical Education, 15: 45-50.

3. Li, S. L. (2018) The research progress of library and information science in Jiangsu Province in the past five years: a bibliometric analysis based on funded papers. New Century Library, 01: 72-74+77.

4. Lin, Q. (2018) Contrastive analysis of international paper output of the library and information science in China under the world-class goal. Library work and Research, 10: 88-94.

5. Ministry of Education of the People's Republic of China. (2019) Opinions of the Ministry of Education on Strengthening Educational Scientific Research in the New Era. http://www.moe.gov.cn/srcsite /A02/ s7049/201911/ t20191107_407332.html. 